ability" in subjects in the pilot study of the two villages is also consistent with this suggestion (Wilson and Matthews, 1966). There may also be an occupational hazard for those engaged in the growing and handling of cassava, though our numbers are too few to advance statistical support for this argument.

That such statistically valid correlations may be biologically coincidental is recognized, and it could be argued that cassava consumption is only indirectly involved, in so far as such heavy dependence on nearly pure carbohydrate could induce nutritional imbalances, particularly of protein, which are of more or less direct aetiopathological significance.

It is interesting to note, however, that differences between Ososa and Akinmorin are relative and not absolute. Not only are there varying amounts of cassava eaten, reflected in varying thiocyanate levels, but this relatively simple clinical survey has also revealed neurological abnormalities among the population at Akinmorin, similar to those at Ososa, though none is of sufficient severity as to constitute a clinically identifiable syndrome, except in one case in the special circumstances described above.

As emphasized elsewhere (Moore, 1930, 1932, 1934a, 1934b, 1937 ; Monekosso and Wilson, 1966 ; Osuntokun, 1968) cassava and cyanogen exposure may be one of several factors. Others could be riboflavine deficiency and abnormalities of vitamin $B_{12}$ metabolism, as well as infections. There may, however, be a conditioned abnormality of cyanide metabolism arising from the low protein intake and consequent lack of substrate (sulphurcontaining amino-acids) for cyanide detoxication (Osuntokun, Durowoju, McFarlane, and Wilson, 1968).

Although there are similarities between this disease and those seen in other tropical and subtropical areas-namely, prisoners of war, and in the West Indies-we féel that it would be unwise at present to assume that these represent clinical variants of the same disease, but obviously it is worth exploring the existence of abnormalities of cyanide metabolism in clinically similar conditions elsewhere.
A therapeutic trial of hydroxocobalamin (as a cyanide antagonist), riboflavine, and cysteine is now in progress.

We wish to thank our colleagues from the Wellcome Trust's working party on tropical neuropathies, the members of which were R. H. S. Thompson (chairman), W. R. S. Doll, M. J. S. Langman, D. M. Matthews, D. L. Mollin, R. D. Montgomery, W. R. Stanton, and P. O. Williams, for their help with this project, which was supported by a grant from the Trust.

\section{REFERENCES}

Aldridge, W. N. (1945). Analyst (Lond.), 70, 474.

Clark, A. (1935). W. Afr. med. F., 8, No. 4, p. 7.

Cruickshank, E. K. (1952). Vitam, and Horm., 10, 2.

Denny-Brown, D. (1947). Medicine (Baltimore), 26, 41.

Ebrahim, G. J., and Haddock, D. R. W. (1964). Trans, roy. Soc. trop. Med. Hyg., 58, 246.

Knüttgen, H. (1955). Z. Tropenmed. Parasit., 6, 472.

Landor, J. V., and Pallister, R. A. (1935). Trans. roy. Soc. trop. Med. Hyg., 29, 121.

Matthews, D. M. (1962). Clin. Sci., 22, 101.

Monekosso, G. L. (1963). f. trop. Med. Hyg., 66, 255. Monekosso, G. L., and Annan, W. G. (1964). Trop. geogr. Med., 16,
316.

Monekosso, G. L., and Ashby, P. H. (1963). W. Afr. med. F., 12, 226.

Monekosso, G. L., and Wilson, J. (1966). Lancet, 1, 1062.

Money, G. L. (1958). W. Afr. med. F., 7, 58.

Moore, D. G. F. (1930). W. Afr. med. ₹., 4, 46.

Moore, D. G. F. (1932). W. Afr. med. f., 6, 28.

Moore, D. G. F. (1934a). Ann. trop. Med. Parasit., 28, 295.

Moore, D. G. F. (1934b). W. Afr. med. F., 7, 119.

Moore, D. G. F. (1937). W. Afr. med. f., 9, 35.

Osuntokun, B. O. (1968). Brain, 91, 215.

Osuntokun, B. O., Durowoju, J. E., McFarlane, H., and Wilson, J. (1968). Brit. med. F., 3, 647.

Scott, H. H. (1918). Ann. trop. Med. Parasit., 12, 109.

Smith, D. A., and Woodruff, M. F. A. (1951) Spec. Rep. Ser. med. Res. Coun. (Lond.), No. 274.

Wilson, J. (1965). Clin. Sci., 29, 505.

Wilson, J., and Matthews, D. M. (1966). Clin. Sci., 31, 1.

\title{
Renal Damage after Acute Pyelonephritis
}

\author{
R. R. BAILEY,* M.B., M.R.A.C.P. ; P. J. LITTLE, $\dagger$ M.B., M.R.C.P. ; G. L. ROLLESTON, $\ddagger$ M.B., D.M.R.D., F.C.R.A.
}

Brit. med. F., 1969, 1, 550-551

\begin{abstract}
Ummary : Intravenous pyelograms done before, during, and after an attack of acute pyelonephritis in a 41year-old woman showed an increase in the size of both kidneys during the attack. The right kidney did not excrete the contrast medium during the acute episode. When function returned it became smaller, and three months after the attack of pyelonephritis this kidney was $1 \mathrm{~cm}$. shorter than before it.
\end{abstract}

\section{Introduction}

It has been difficult to show that acute renal infection in the adult causes any permanent renal damage. It is believed that in the case described here such damage has been demonstrated.

* Senior Medical Registrar, Christchurch Hospital, Christchurch, New Zealand.

t Renal Physician, Christchurch Hospital, Christchurch, New Zealand.

$\ddagger$ Director of Radiology, Christchurch Hospital, Christchurch, New Zealand.

\section{Case Report}

A 41-year-old spinster was admitted to hospital on 13 June 1968. In January 1968 an intravenous pyelogram was normal (Fig. 1). This investigation was carried out because of suspected haematuria. The finding of haematuria was not confirmed. Three urine cultures were sterile. Eight days before admission a dilatation and curettage was carried out because of menorrhagia. The bladder was catheterized previous to this procedure.

Forty-eight hours after curettage she developed intense terminal dysuria and frequency and noted her urine to be smelly and frothy. She had bilateral loin pain, fever, rigors, headache, and vomiting. A midstream urine culture grew over 100,000 coliform bacilli per ml. Ampicillin $250 \mathrm{mg}$. six-hourly was given.

On admission a diagnosis of acute pyelonephritis was made. Oral temperature was $38 \cdot 2^{\circ} \mathrm{C}$. and blood pressure $100 / 60 \mathrm{~mm}$. Hg. A midstream urine obtained on the day of admission had 6-10 leucocytes and over 50 red cells per high-power field and grew 3,000 klebsiella per ml. Blood culture grew klebsiella sensitive to kanamycin, cephaloridine, and tetracycline and resistant to ampicillin and sulphonamides. 
The day after admission a urine specimen obtained by suprapubic bladder aspiration grew klebsiella. The quantitative leucocyte count was $420 / \mathrm{cu}$. mm. and red cell count $150 / \mathrm{cu}$. mm. The packed cell volume was $43 \%$, white blood cell count $14,000 / \mathrm{cu}$. mm., and the E.S.R. $70 \mathrm{~mm}$./hour. Blood urea was $40 \mathrm{mg} . / 100 \mathrm{ml}$, , serum sodium $139 \mathrm{mEq} / \mathrm{l}$., serum potassium $4.5 \mathrm{mEq} / \mathrm{l}$., serum creatinine $1.2 \mathrm{mg} . / 100 \mathrm{ml}$., and creatinine clearance $50 \mathrm{ml} . / \mathrm{min}$. Urine concentration after 5 units of Pitressin in oil was $596 \mathrm{mOsm} / \mathrm{kg}$. $\mathrm{H}_{22} \mathrm{O}$, and urine $p \mathrm{H}$ after $7 \mathrm{~g}$. ammonium chloride was $4 \cdot 85$.

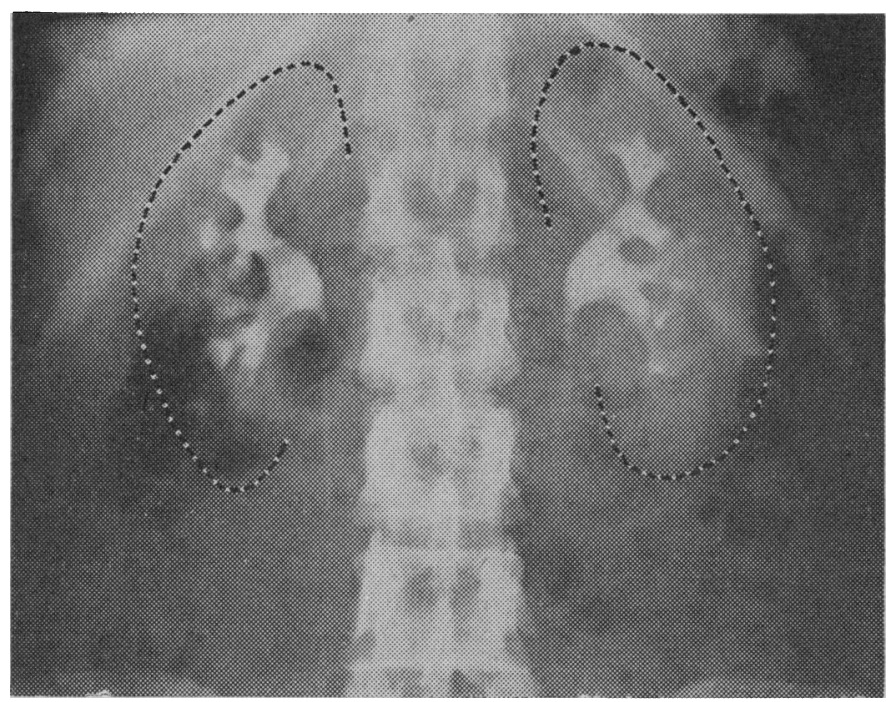

FIG. 1.- Intravenous pyelogram three months before the attack of acute pyelonephritis.

After the diagnosis was confirmed treatment was started with trimethoprim $160 \mathrm{mg}$. and sulphamethoxazole $800 \mathrm{mg}$. twice daily for one weck. A rapid clinical improvement occurred but a mild pyrexia persisted. The urine became sterile but the leucocyte concentration remained above $400 / \mathrm{cu}$. mm. Repeat blood cultures were sterile.

An intravenous pyelogram performed on the second day of admission (Fig. 2) showed the left kidney to be apparently normal but slightly larger than previously. The right kidney failed to excrete any contrast after seven and a half hours, and there was no sign of any nephrographic filling. The kidney was well visualized and was considerably enlarged, measuring $14.8 \mathrm{~cm}$. in length and $7 \cdot 7 \mathrm{~cm}$. in width (see Table).

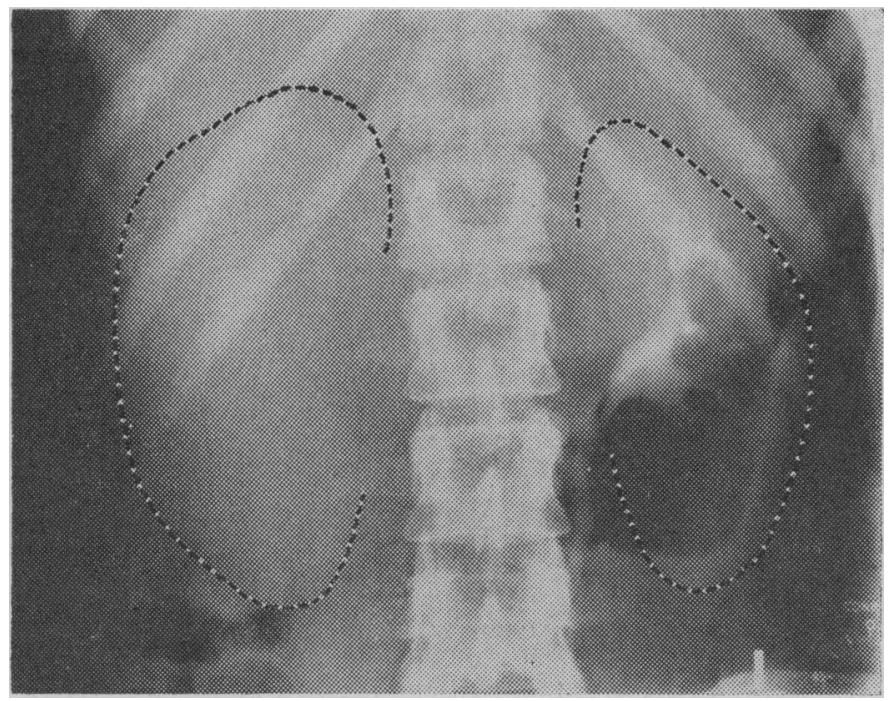

FIG. 2.-Intravenous pyelogram during the attack of acute pyelonephritis. The right kidney has not excreted contrast material and both kidneys have increased in size.

Five days after admission a right retrograde pyelogram (Mr. W. L. F. Utley) showed no ureteric obstruction or dilatation. Cystoscopy was also normal.
Measurements of Renal Length and Thickness Before, During, and After the Attack of Acute Pyelonephritis

\begin{tabular}{|c|c|c|c|c|}
\hline \multirow{2}{*}{\multicolumn{2}{|c|}{ Date }} & & \multicolumn{2}{|c|}{ Kidney Measurements $(\mathrm{cm})}$. \\
\hline & & & Right & Left \\
\hline $\begin{array}{l}21 \text { March } 1968 \\
14 \text { June .. } \\
21 \text { June . } \\
5 \text { August } \\
3 \text { September }\end{array}$ & $\begin{array}{l}\cdots \\
\cdots \\
\cdots\end{array}$ & $\begin{array}{l}\ldots \\
\cdots \\
\cdots\end{array}$ & $\begin{array}{l}12.5 \times 5.6 \\
14.8 \times 7.7 \\
14.0 \times 7.1 \\
12.3 \times 5.4 \\
11.5 \times 5.1\end{array}$ & $\begin{array}{l}12.6 \times 6.0 \\
13.7 \times 6.5 \\
13.6 \times 6.4 \\
12.7 \times 6.0 \\
12.6 \times 6.0\end{array}$ \\
\hline
\end{tabular}

The intravenous pyelogram was repeated nine days after admission and again the left kidney was normal but the right kidney had begun to excrete contrast. Excretion was delayed and depressed compared with that of the left kidney. There was no obstruction to drainage and the bladder emptied completely after micturition. The creatinine clearance was now $60-72 \mathrm{ml} . / \mathrm{min}$.

Nineteen days after the onset of the illness a right percutaneous renal biopsy was performed. This showed extensive polymorphonuclear infiltration of the interstitial spaces and the tubules were packed with cellular debris. The changes were those of acute pyeionephritis.

After further antibiotic therapy the fever settled and the patient was discharged. The creatinine clearance was now $90 \mathrm{ml} . / \mathrm{min}$. The urine contained 420 leucocytes per cu. $\mathrm{mm}$. and was sterile. The white blood cell count had fallen to normal and the E.S.R. to $42 \mathrm{~mm}$./hour. Six weeks later the urine was still sterile but contained 50 leucocytes per cu. mm. An intravenous pyelogram was carried out 10 weeks after admission (Fig. 3). No caliceal clubbing or visible scars had developed in either kidney but the right kidney was $1 \mathrm{~cm}$. shorter than before the attack of pyelonephritis.

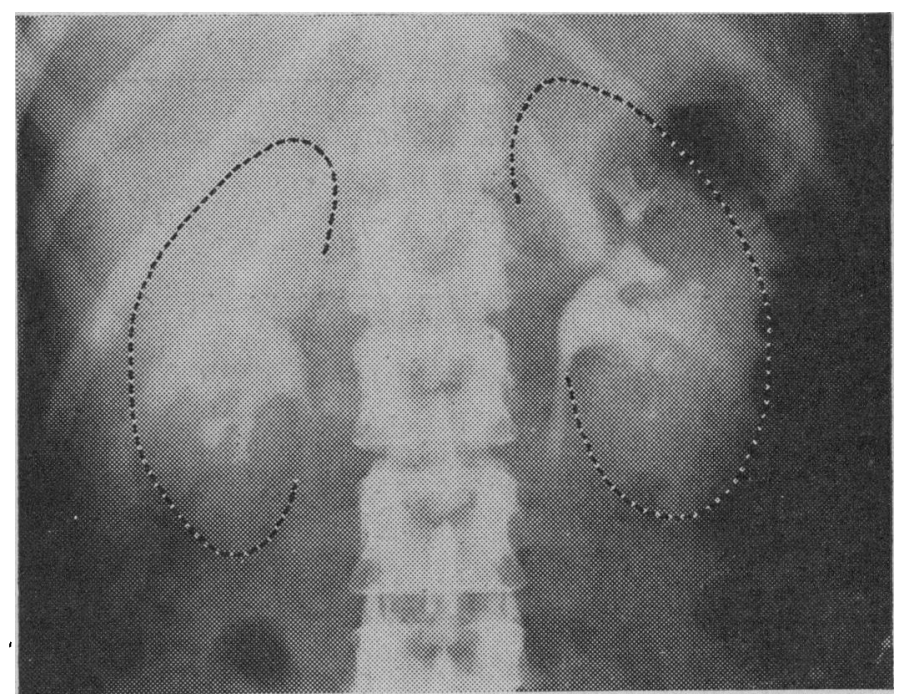

FIG. 3.- Intravenous pyelogram three and a half months after the attack of acute pyelonephritis. The right kidney is now $1 \mathrm{~cm}$. shorter than in Fig. 1 .

\section{Discussion}

Radiological changes during and after an attack of acute pyelonephritis have been described (Little, McPherson, and de Wardener, 1965). Because of the lack of investigations before the symptomatic episode it was only possible to assume that permanent damage to renal tissue had occurred.

In the above case both kidneys increased in size and the right kidney ceased to excrete contrast during the acute episode. Function returned to this kidney but the organ gradually diminished in size and was eventually $1 \mathrm{~cm}$. shorter than before the attack of pyelonephritis. The diagnosis of acute pyelonephritis was confirmed by renal biopsy and it is believed that this patient suffered from reduction in renal mass as a consequence of this disease.

\section{REFERENCE}

Little, P. J., McPherson, D. R., and de Wardener, H. E. (1965). Lancet, 1, 1186. 